\title{
Psychosocial aspects of entrepreneurial potential
}

\author{
Susana Correia Santos ${ }^{\mathrm{a} *}$, António Caetano ${ }^{\mathrm{a}}$ and Luís Curral ${ }^{\mathrm{b}}$ \\ ${ }^{a}$ Instituto Universitário de Lisboa (ISCTE - IUL), BRU—IUL, Avenida das Forças Armadas, \\ Edifício ISCTE, -Lisboa 16749-026, Portugal, ${ }^{b}$ Faculty of Psychology, Lisbon University, Alameda \\ da Universidade, Lisboa 1649-013, Portugal
}

This study presents a theoretical model regarding the entrepreneurial potential construct, and the main psychosocial aspects that contribute towards an individual's preparedness to engage in activities typically associated with entrepreneurship. The general question addressed in this study is: How to explain the entrepreneurial potential construct theoretically, and how to assess it empirically? This study seeks to contribute by creating an instrument (the EPAI - Entrepreneurial Potential Assessment Inventory) that can be used to measure the entrepreneurial potential construct. In this paper we present four studies on its empirical validation. The results suggest reliable scale characteristics, convergent and discriminant validity. The EPAI can be used by an entrepreneur for self-assessment, for training, and for professional development.

Keywords: entrepreneurial potential; scale development; entrepreneur; competencies

Cette étude présente un modèle théorique relatif au construit d'un potentiel d'entreprise, ainsi que les principaux aspects psychologiques contribuant à la préparation d'un individu dans la mise en place d'activités généralement associées à l'entreprenariat. La question générale à laquelle cette étude s'adresse est : Comment expliquer théoriquement le construit d'un potentiel d'entreprise et comment l'évaluer empiriquement? Cette étude espère contribuer à la réponse à cette question en créant un instrument (l'EPAI - Inventaire d'évaluation du potentiel d'entreprise) pouvant être utilisé pour mesurer le construit du potentiel d'entreprise. Cet article présente quatre études sur sa validation empirique. Les résultats indiquent des caractéristiques d'échelle fiables, ainsi qu'une validité convergente et discriminante. L'inventaire d'évaluation du potentiel d'entreprise peut être utilisé par un entrepreneur pour l'autoévaluation, la formation et le développement professionnel.

Mots clés: potentiel d'entreprise; développement d'échelle; entrepreneur; compétences

\section{Introduction}

More than 80 years after the seminal contributions of Schumpeter (1934), entrepreneurship research is becoming a more established field with its own theoretical, empirical, and methodological debates (for example, Blackburn and Kovalainen 2009). However, there are still theoretical, empirical, and applied aspects that require more in-depth attention. One such aspect is to do with explaining the individual psychosocial dimensions that are related to the preparedness to engage in entrepreneurial activities. 
The present study approaches the entrepreneurship phenomena from an individual perspective. We propose that individuals have a latent potential to become entrepreneurs. This potential is the summative result of a set of distinctive competencies and motivations that are the manifest aspects of every individual's preparedness to become an entrepreneur.

This study aims to make a contribution to the development of the theoretical and empirical field of entrepreneurship by presenting a model for entrepreneurial potential and measurement. The main question underpinning this research is: How to explain the entrepreneurial potential construct theoretically, and how to assess it empirically? We propose a theoretical model of entrepreneurial potential that builds on the main previous evidences from empirical and descriptive studies. The entrepreneurial potential construct includes four main dimensions: entrepreneurial motivations, management competencies, psychological competencies, and social competencies. These four main dimensions include a total of 11 subdimensions.

Based on this theoretical model, we present a measurement instrument: the Entrepreneurial Potential Assessment Inventory (EPAI). We present a set of four empirical studies that contribute to evidence the validity of the instrument. Study 1 describes how the items were created and their operationalization. Studies $2 \mathrm{a}$ and $2 \mathrm{~b}$ test the construct validity and the psychometric characteristics of the scale in two samples. We conduct confirmatory factor analysis, and results show that the EPAI captures accurately the proposed theoretical model of the entrepreneurial potential. Study 3 focuses on the convergent validity, and results show that our scale was positively and significantly correlated with a related construct: enterprise potential. Moreover, study 3 also analyzes the discriminant validity, and results show that the EPAI discriminates among participants with high and low levels of entrepreneurial intentions and internal locus of control. In addition, results also indicate that the external locus of control is not associated with the overall measure on the entrepreneurial potential. Finally, study 4 focuses on the comparison of the results of entrepreneurial potential among university students, young employees, and the entrepreneurs. General results follow our prediction that entrepreneurs score higher in the entrepreneurial potential dimensions and subdimensions than the other groups.

Theoretically, this study contributes to the development of a conceptual model about entrepreneurial potential. Methodologically, we present a scale with reliable characteristics to measure this entrepreneurial potential. This measure can be used as a self-assessment tool for future entrepreneurs, and also can contribute to diagnose specific training needs.

\section{Entrepreneurial potential}

Krueger and Brazeal (1994) developed theoretical propositions on a model of entrepreneurial potential based on three critical constructs: perceived desirability, perceived feasibility, and propensity to act. The authors conceptualize potential entrepreneurs as those with an entrepreneurial potential. This is defined as a process of interaction between perceived desirability (including social norms and attitudes), perceived feasibility (that is, self-efficacy), and propensity to act. The entrepreneurial potential, as Krueger and Brazeal (1994) conceptualize it, is prior of entrepreneurial intentions, in such a way that an individual can have a high entrepreneurial potential but does not consider engaging in an entrepreneurial activity, and vice versa.

Despite the relevance of Krueger and Brazeal (1994) theoretical paper, the theme of entrepreneurial potential has been quite fuzzy in the literature. More specifically, entrepreneurial potential literature lacks (a) a consensual definition of entrepreneurial potential; (b) a conceptualization of entrepreneurial potential manifestation and measurement; and 
(c) a explanation about the level of analysis of entrepreneurial potential. We explain these aspects in detail on the following paragraphs and show why they need clarification.

Krueger and Brazeal (1994) described the process based on Ajzen's theory of planned behavior and on Shapero's model of the entrepreneurial event. However, the authors did not present a definition of entrepreneurial potential. One definition of entrepreneurial potential was offered by Raab, Stedham, and Neuner (2005), arguing that it 'is the extent to which an individual possesses the characteristics that are associated with successful entrepreneurs' (72).

Focusing on the manifestation and measurement, Krueger and Brazeal (1994) assumed theoretically that the entrepreneurial potential is a latent expression of the perceived desirability, perceived feasibility, and propensity to act. Other empirical approaches (for example, Raab, Stedham, and Neuner 2005) suggested that the entrepreneurial potential was expressed by seven characteristics: need for achievement, locus of control, propensity to take risks, problem solving, willingness to assert oneself, tolerance of ambiguity, and emotional stability. The enterprise potential was assessed among university students using a scale comprising four main attitudes towards characteristics associated with entrepreneurship: leadership, creativity, achievement, and personal control scale (Athayde 2009).

Entrepreneurial potential is defined both at the individual level (for example, Krueger and Brazeal 1994; Raab, Stedham, and Neuner 2005; Wong, Cheung, and Venuvinod 2005; Athayde 2009) and at the country level (for example, Mueller and Thomas 2000; Mueller and Goić 2002; Mueller 2004; Harada 2005; Nguyen et al. 2009). These examples evidence the different levels of conceptualization of the construct.

In the present study, we aim to clarify the definition, measurement, and level of the construct of entrepreneurial potential. We next present the theoretical proposal reasoning of the entrepreneurial potential construct.

\section{Theoretical positioning for the construct}

The entrepreneurship process is deeply linked to an individual's characteristics (Baum et al. 2007) given that he/she is the main agent in the process of deciding to implement entrepreneurial initiatives, and to assume responsibility for the consequences. This perspective is then focused on the cognitions, actions, decisions, aspirations, and emotions of the entrepreneur (Venkataraman et al. 2012). Despite the relevance of both the individual and the organizational constructs, this study focuses exclusively on the individual level. Our focus on the individual level is strengthened by the importance individual characteristics have on the entrepreneurial process (for example, Baum and Locke 2004; Baron and Shane 2008; Baron 2013). We assume that entrepreneurship is not solely the result of an individual's actions and characteristics, as external factors also play a relevant role (for example, the economic, technological, political, and regulatory context).

We support the choice of the individual perspective based on the evidence that entrepreneurship is a human based practice and intrinsically dependent on the individuals' decisions and actions. In fact, there is no entrepreneurship without the individual. Or, as McMullen and Shepherd (2006) stated, 'Entrepreneurship requires action' (132) and action requires individuals. Following this argument, we define the entrepreneurial potential construct in the individual level of analysis.

Entrepreneurial intention (for example, Ajzen 1991; Krueger, Reilly, and Carsrud 2000; Liñán and Chen 2009) is one of the most cited constructs at the individual level in the pre-emergence stage, and is also one of the best predictors of behavior (Ajzen 2002). 
Krueger and Brazeal (1994) suggested that the entrepreneurial potential is prior to the entrepreneurial intentions. In fact, having the potential to be an entrepreneur does not imply that the individual wish to make use of it, or that the environment and context is favorable for it. Thus, an individual can have a high potential to be an entrepreneur, but does not consider to launch a venture (that is, does not have an entrepreneurial intention). We share this vision about the relation between entrepreneurial potential and intentions. The former refers to the individual perception about its capacity and the later refers to the wish to engage in entrepreneurship activities.

Generally, research has focused on identifying and describing the psychosocial characteristics that differentiate entrepreneurs from managers (for example, Chen, Greene, and Crick 1998; Brandstätter 2011), that are associated with venture growth (Baum, Locke, and Smith 2001) and attitudes towards entrepreneurship in students (Athayde 2009), among others.

Previous research at the individual level focused mainly on attitudes (Athayde 2009), personality traits (Brandstätter 2011), skills (Baum and Locke 2004), and motivations (Shane, Locke, and Collins 2003). The entrepreneurship context affords a wide range of freedom to choose and change tasks according to personal preferences and goals. The personality traits and cognitive ability of entrepreneurs are obviously important when it comes to successfully performing varied activities and tasks in a complex and uncertain environment. However, they are not the only aspects that enable entrepreneurs to successfully respond to the socio-economic circumstances they have to face. Other competencies, since they are specifically related to the performance criteria of job tasks go beyond personality traits and cognitive ability. Competencies complement personality traits and cognitive ability, and contribute to explain the entrepreneurship process.

Thus, we argue that the construct of entrepreneurial potential is more accurately represented through a competency-based model that expresses the dynamics involved in entrepreneurial activities. We propose a competency-based model for entrepreneurial potential and have adopted the definition suggested by Spencer and Spencer (1993, 9): 'A competency is an underlying characteristic of an individual that is causally related to criterion-referenced effective and/or superior performance in a job or situation'.

Based on the Krueger and Brazeal's (1994) assumptions and Spencer and Spencer's (1993) competency definition, we consider that entrepreneurial potential refers to an individual's preparedness to engage in typical entrepreneurial activities. Our definition captures the construct of entrepreneurial potential as an ability that can be developed and that is not only associated with successful entrepreneurs. Thus, the definition we propose is wider and more integrative than previous (for example, Raab, Stedham, and Neuner 2005). By focusing on entrepreneurial potential we intend to highlight the developmental process of typical entrepreneurial skills.

In accordance to our definition, the entrepreneurial potential is the latent construct that expresses the most distinctive characteristics associated with the performance in entrepreneurial activities. In other words, we propose that entrepreneurial potential is the summative result of several individual entrepreneurial characteristics. The theoretical reasoning underpinning the conceptualization of entrepreneurial potential is that individuals have a psychosocial profile that can be compared with the psychosocial profile of the majority of entrepreneurs.

Thus, by bringing together the most relevant and discriminative characteristics in the entrepreneur literature, we can put together a compilation of the psychosocial characteristics most shared among entrepreneurs. This compilation is at the essence of the entrepreneurial potential of individuals, once that it enunciates the multi-dimensions that express 
an individual's preparedness to engage in activities that typify entrepreneurship. In other words, entrepreneurial potential, at the individual level, could represent the essence of the entrepreneur.

Connecting prior research evidence from entrepreneur literature, theoretical developments, and the predicted relationships between the constructs and variables, we next present a summary organized according to the main dimensions of the construct domain: entrepreneurial motivations, management competencies, psychological competencies, and social competencies. The literature shows that included in these main dimensions are several subdimensions that are considered more distinguishing of entrepreneurial behavior or entrepreneurial identity (Anderson and Warren 2011). However, it is not our purpose here to develop a systematic literature review of the characteristics of entrepreneurs because good state of the art overviews of psychological entrepreneurship research have already been provided, for example, meta-analysis (for example, Schwenk and Shrader 1993).

We propose that the entrepreneurial potential construct is the latent expression of these four main dimensions (entrepreneurial motivations, management competencies, psychological competencies, and social competencies). We present next a revision organized by these four dimensions, including also the main subdimensions.

\section{Entrepreneurial motivations}

By entrepreneurial motivations we refer to the motives that drive individuals towards typical entrepreneurial activities. Human motivation is one of the more significant predictors of entrepreneurial success. It is the main driver in pursuing entrepreneurial opportunities (Santos, Curral, and Caetano 2010), assembling resources, and engaging in the entrepreneurial process (Shane, Locke, and Collins 2003).

The entrepreneurial motivations highlighted in the literature include general and taskspecific levels, with different impacts on the entrepreneurial process (Shane, Locke, and Collins 2003) and venture growth (Baum, Locke, and Smith 2001). The rich complexities of motivations were engaged as a critical role in entrepreneurial behaviors. According to the literature, three main drivers can express entrepreneurial motivation: desire for independence, economic motivation, and entrepreneurial self-efficacy.

\section{Desire for independence}

Entrepreneurs frequently acknowledge that they are driven by a desire for independence, showing that they want the authority to take the important decisions:

Independence entails taking the responsibility to use one's own judgement as opposed to blindly following the assertions of others. It also involves taking responsibility for one's own life rather than living off the efforts of others. (Shane, Locke, and Collins 2003, 268).

Hisrich (1985) found that one of the prime motivations for starting a business was a desire for independence. Hornaday and Aboud (1971) showed that founders scored significantly higher than the general population on measures of independence.

\section{Economic motivation}

The desire to pursue entrepreneurial opportunities to generate economic profit, that is, the economic motivation, has been cited as one of the characteristics most shared by successful 
entrepreneurs: the need to make money. In general, entrepreneurs perceived their work as more profitable than working for others (for example, Brice and Nelson 2008).

\section{Entrepreneurial self-efficacy}

An individual's belief in his/her capacity to pursue a particular goal has been identified as crucial to several activities (Bandura 1997) and entrepreneurial activity is no exception. Self-efficacy is important for entrepreneurs because they must be confident in their abilities to perform different and often unanticipated tasks in uncertain situations (Baum and Locke 2004).

Individuals with high self-efficacy were likely to persist when problems arose, and actively sought out challenges and, by extension, challenging opportunities (Bandura 1997). Self-efficacy has been related to business venture launch and success (Chen, Greene, and Crick 1998), and dynamics around business performance (Hmieleski and Baron 2008).

\section{Management competencies}

Entrepreneurs also need to possess the hard skills that enable them to manage a business the management competencies. Across the entrepreneurial process, individuals must have the specific skills they need to manage a venture. The management competencies are defined by the basic and specific competencies in business management (for example, Baum, Locke, and Smith 2001), and mostly they refer to the individual's ability to manage the entrepreneur himself/herself, business strategy, business resources, and human resources.

\section{Vision}

Despite the diversity of definitions for vision, it is nevertheless generally acknowledged to be an idealized goal to be achieved in the future or an ideal and unique image of the future (Kirkpatrick, Wofford, and Baum 2002). Greenberger and Sexton (1988, 5) argued that 'entrepreneurs are likely to have some abstract image in mind about what they intend to accomplish', and this vision serves as a guide for their own actions.

Empirically, vision capacity has been shown to be a predictor of entrepreneurial venture development (Baum, Smith, and Locke 2001). Baum, Locke, and Kirkpatrick (1998) found direct and indirect causal effects of vision attribute, vision content, and vision communication on small venture performance.

\section{Resource mobilization capacity}

The ability to marshal the financial and material resources to manage a venture has been identified as an important predictor of entrepreneurial success, given that resources are an essential feature of new venture development and make it easier for new ventures to adjust to complex environments (for example, Tan and Peng 2003). Financial resources serve to acquire other resources in such a way that provides a venture with strategic flexibility and facilitates its adjustment to complex environments (Tan and Peng 2003). Accordingly to Chell, Haworth, and Brearley (1991), a prototypical entrepreneur is alerted to business opportunities regardless of resources currently controlled, is innovative, and uses a variety of sources of finance. 


\section{Leadership capacity}

Leadership research has shown that leadership emergence is greatly affected by personality traits (Lord, DeVader, and Alliger 1986). Entrepreneurial leadership has been identified as important and has been described as the ability to influence others, to manage resources strategically in order to emphasize both opportunity-seeking and advantage-seeking behaviors (Ireland, Hitt, and Simon 2003; Todorovic and Scholosser 2007).

\section{Psychological competencies}

There is a broad set of characteristics that can be included among the psychological competencies, and they refer to the wide group of skills and attributes which characterize entrepreneurial individuals (for example, Chell 2008). Within that set are situational characteristics that are often common to all entrepreneurs: an absence of other people giving orders, the need for emotional stability, demand for social contact, and a readiness to respond to change and try out new ideas. In the group of psychological competencies we include the individual traits that are distinctive among entrepreneurs.

\section{Innovation capacity}

The capacity for innovation is one of the main characteristics of the entrepreneurial human capital (for example, Marvel and Lumpkin 2007). While innovativeness can be defined as a characteristic of an individual, innovation implementation effectiveness depends on a group of persons, and as such is a characteristic of an entrepreneurial venture (Klein and Sorra 1996; Kreiser and Davis 2010). It is possible to distinguish entrepreneurs from non-entrepreneurs based on achievement, self-esteem, personal control, and innovation (Robinson et al. 1991).

\section{Emotional intelligence}

Mayer, Salovey, and Caruso (2000) defined emotional intelligence as an ability to express emotions, to use emotions to facilitate thinking, to understand and argue by means of emotions, and to manage them internally while communicating with others effectively.

Previous research has shown that entrepreneurs get relatively high scores for emotional intelligence (Baron and Markman 2000). The Zampetakis et al. (2009) model showed that emotional components were expressed by feelings and emotions, determining attitude towards entrepreneurial intentions.

\section{Resilience}

In entrepreneurship, the uncertainty level is generally higher than in other organizational settings, and entrepreneurs have to know how to design and implement adaptable behaviors.

Empirical research evidenced that entrepreneurs showed greater levels of persistency than non-entrepreneurs (for example, Friborg et al. 2006). Given that entrepreneurship is strictly associated with risk, it was relevant to analyze an entrepreneur's ability to cope with difficulties, threats, and unsuccessful projects. We argue that resilience must be an important factor across the entrepreneurship process, as the level of uncertainty faced by entrepreneurs is greater than that of other organizational players. In addition, it was 
shown that entrepreneurs could develop emotional, cognitive, social, and financial resilience that can be harnessed and mobilized for a subsequent venture launch (Hayward et al. 2010).

\section{Social competencies}

Since an entrepreneur acts within a social context and therefore has to interact with different players, another dimension of an entrepreneur's characteristics that would denote an individual's ability to interact effectively with others involves social competence. An entrepreneur's effectiveness in interacting with others, that is, his or her social competence, may also affect their entrepreneurial success (Baron and Markman 2000). This assumption was based on predicting that the higher an entrepreneur's social competence, the greater the success of his or her business.

\section{Persuasion and communication capacity}

The ability to interact effectively with others has a positive effect on entrepreneurial success (Baron and Markman 2000). Entrepreneurs consider that they have a greater capacity for persuasion (Hoehn-Weiss, Brush, and Baron 2004). Recent studies evidenced that the social competencies relate significantly to new venture performance measures, and this relationship is mediated through success in information seeking and resources (Baron and Tang 2009).

\section{Network development capacity}

The ability to develop a network between entrepreneurs and other individuals who can provide resources for business implementation and development was identified as one of the entrepreneurial performance predictors (Baughn et al. 2006). The ability to develop a social network, together with other constructs, has a direct effect on venture creation development (for example, Lee and Tsang 2001). The network approach assumes that an entrepreneur's ability to organize and coordinate networks between individuals and organizations was critical for both starting up a company and business success (Birley 1985).

\section{The entrepreneurial potential construct}

Based on the assumption that the same main dimensions that are typical of entrepreneurs are critical in assessing an individuals' preparedness to engage in typical entrepreneurship activities, that is, an individuals' entrepreneurial potential, we suggest that entrepreneurial potential can be explained by the four main dimensions evidenced in the literature on entrepreneur characteristics.

The four main dimensions that can explain entrepreneurial potential are: (1) entrepreneurial motivations; (2) psychological competencies; (3) social competencies; and (4) management competencies. These dimensions allow us to identify and differentiate entrepreneurial potential. Connecting the dots to bring together the most outstanding aspects of previous empirical research and theoretical suggestions, a review of the literature highlighted 11 subdimensions These four main dimensions of the entrepreneurial potential include motivations and competencies. Motivations and competencies coexist in the entrepreneurial potential model because both are individual characteristics that can be developed over time and that capture the dynamics of individuals' interests and career paths. 
Bearing in mind that entrepreneurial potential is conceptualized as an individual's preparedness to engage in entrepreneurial activities, it is important to develop an assessment inventory based on the proposed theoretical model that would allow us to assess the entrepreneurial potential construct. Furthermore, it is essential to encourage young university students and young employees to develop a flair for entrepreneurship and innovation (for example, Carey, Flanagan, and Palmer 2010). Despite extensive entrepreneurial programs and the emphasis on academic entrepreneurship, knowledge about the individuals' preparedness to engage in typical entrepreneurship activities, that is, their entrepreneurial potential, is still scant. It is important that an individual aspiring to be an entrepreneur is able to assess himself or herself against an entrepreneurial profile before undertaking the personal and professional risks of a start-up venture (Osborne 1995).

Frequently, we evidenced that assessment instruments refer to the operationalization of one specific psychological construct such as entrepreneurial self-efficacy (for example, McGee et al. 2009), or proactive personality scale (Crant 1996).

These scales were not sufficient to assess a pattern or a typical entrepreneurial competencies profile (Lumpkin, Cogliser, and Schneider 2009) because: (1) theoretically, there were different conceptualizations of the same construct and the fact several psychological traits were not integrated meant that all of the most distinctive individual dimensions would be compromised; (2) methodologically, there were different scales developed to assess the same construct and most of them inadequately fulfill the validation and psychometric requirements; (3) the existing assessment scales were not sufficient to be applied to the entrepreneurial activity because they are time-expensive, the coding system is difficult, not comparable among each other; nor are they possible for the entrepreneurship players to intuit.

Despite previously mentioned research on intention to launch a venture and on entrepreneurial potential, there are theoretical gaps and the need to develop a workable assessment inventory is clear.

Consequently, and in an attempt to plug these gaps, the present study seeks to contribute by creating an instrument to measure the entrepreneurial potential construct - the EPAI.

To broaden our understanding of the entrepreneurial potential construct, we sought to address the methodological and psychometric shortcomings associated with the entrepreneurial potential measure. To that end, we performed four studies. Study 1 explains how the items for the inventory were created and presents a description of measures. Studies $2 \mathrm{a}$ and $2 \mathrm{~b}$ show the construct validity using a sample of university students (study $2 \mathrm{a}$ ) and young employees (study $2 \mathrm{~b}$ ). Convergent validity is assessed using a measure of enterprise potential, and discriminant validity is analyzed using measures of locus of control and entrepreneurial intention (study 3). Finally, study 4 compares the results of the inventory between university students, young employees, and entrepreneurs. We next present the four studies.

\section{Study 1 - Entrepreneurial potential assessment inventory: item selection and content validity screening with entrepreneurs}

Upon creating an initial pool of items for the scale, we conducted 12 semi-structured interviews with first-time entrepreneurs, which aimed at assessing the adjustment between the theoretical dimensions emerging from the literature review and the entrepreneurial context.

Based on the interviews and on previous literature (for example, Baron and Markman 2000; Brice and Nelson 2008; Chen, Greene, and Crick 1998) we compiled a first 
inventory version of 84 items. To assess the fit to the entrepreneurial context, this first version of the inventory was discussed with six other entrepreneurs. The entrepreneurs completed the scale and indicated which of the items were ambiguous or confusing.

Following that analysis, we compiled a second version with 46 items including several adapted from the previous version and others specifically created for the EPAI.

The pool of 46 items on the EPAI included the following operationalization:

The desire for independence was measured by four items as, for example, 'One of the most important things to me is having a job where I'm my own boss'.

Economic motivation was measured by four items (for example, 'I will do my best to make as much money as possible').

Entrepreneurial self-efficacy was measured by four items, among them were: 'When I decide to start any business project, I know I will see it through'.

Vision was measured by four items (for example, 'I can see clearly how to implement unlikely initiatives').

Resource mobilization capacity was measured by five items like, for example: 'Normally, I can find the resources to implement the initiatives I have'.

Leadership capacity was measured with five items, as for example, 'Usually I can mobilize people for the initiatives I propose'.

Innovation capacity was measured by four items, as for example, 'People often ask me for help with creative activities'.

Emotional intelligence was measured by four items (for example, 'I easily recognize my emotions as I experience them').

Resilience was measured by four items, as for example, 'In difficult times I tend to focus on what helps me to overcome them'.

Communication and persuasion capacity was measured by four items (for example, 'In most situations I can make other people to do what I want').

Network development capacity was measured by four items, as for example, 'I know people from a variety of different places'.

These were the pool of items used in studies $2 \mathrm{a}$ and $2 \mathrm{~b}$ in order to test the scale's psychometric characteristics and its construct validity.

\section{Study 2a - Scale psychometric characteristics among university students}

This study aims to test the psychometric characteristics of the EPAI. More specifically, we aim to test if the four main dimensions and the 11 subdimensions we propose are the expression of the latent construct of entrepreneurial potential. Furthermore, we will analyze if the items included in each dimension are the most appropriate.

\section{Sample and method}

This study included a sample of 521 university students, all aged between 17 and 30 years old, with a mean age of $22(S D=4.2)$. The majority of the students were female $(62.3 \%)$, undergraduates $(92 \%)$ and $8 \%$ were doing a master's degree. 
For each item, respondents indicated the level of agreement or disagreement with different sentences on a scale ranging from 1 (completely disagree) to 5 (completely agree).

To test whether the 46 items selected captured the proposed theoretical model of entrepreneurial potential, we began by conducting an exploratory factor analysis. The preliminary results evidenced adequacy on the four-factor solution, with $47 \%$ of variance explained. The subdimensions considered are the subset of the dimensions addressed by the survey that factored together as part of an exploratory factor analysis. The results of the factor loadings suggested that entrepreneurial self-efficacy loads the management competencies dimension. Thus, we tested the model using confirmatory factor analysis using AMOS software, following the evidences from the exploratory analysis, and including entrepreneurial self-efficacy of the management competencies. In accordance with the classic model of survey development conducted by factor analysis (Kline 1993) we performed preliminary factor analyses, although in the interest of economy we do not present here a detailed description of it. However, the results showed that the loadings of some items were not appropriate and consequently, we have removed them from the final model. Thus, the best confirmatory model for the operationalization of entrepreneurial potential that we have arrived at comprises 33 items.

\section{Main results}

Figure 1 presents the confirmatory model of the EPAI. The model includes the four main dimensions (entrepreneurial motivation, management competencies, psychological competencies, and social competencies) and the 11 subdimensions.

The confirmatory factor analysis of the EPAI was developed in two distinct stages. First, we tested each of the four dimensions' confirmatory models. The results evidenced good fit indexes for the four models tested separately: model of entrepreneurial motivations - Comparative Fit Index (CFI) 1/4 0.99; Root Mean Square Error of Approximation (RMSEA) 1/4 0.03; Standardized Root Mean Square Residual (SRMR) 1/4 0.02; model of management competencies - CFI 1/4 0.95; RMSEA 1/4 0.04; SRMR $1 / 40.03$; model of psychological competencies - CFI 1/4 0.95; RMSEA 1/4 0.03; SRMR 1/4 0.03; and model of social competencies - CFI 1/4 0.97; RMSEA 1/4 0.05; SRMR 1/4 0.04.

Next, the EPAI model, including the 33 items, was developed (see Figure 1). The fit indexes for the university student sample $\left(\chi^{2}=785.60 ;\right.$ d.f. $=454 ; p<0.01 ; \chi^{2} / d . f$. $=$ $1.73 ; C F I=0.90 ; R M S E A=0.04 ; S R M R=0.05)$ evidence an adequate fit of the data to the model. The standardized regression coefficients of the four main dimensions are: $B_{\text {entrepreneurial motivation }}=0.34^{* *} ; B_{\text {management competencies }}=0.97^{* *},{ }^{* *} p<0.01 ; B_{\text {psychological }}$ competencies $=0.85^{* *} ; B_{\text {social competencies }}=0.62^{* *}$.

This result supports the construct validation of the theoretical model proposed for the operationalization of the entrepreneurial potential construct (Byrne 2004). Thus, there are theoretical and empirical arguments to support the 11 subdimensions.

\section{Study $2 b$ - Scale psychometric characteristics among young employees}

This study aims to test again the psychometric characteristics of the EPAI in a different sample. By using a sample of young employees we can analyze how the construct dimensions perform in such a sample. 


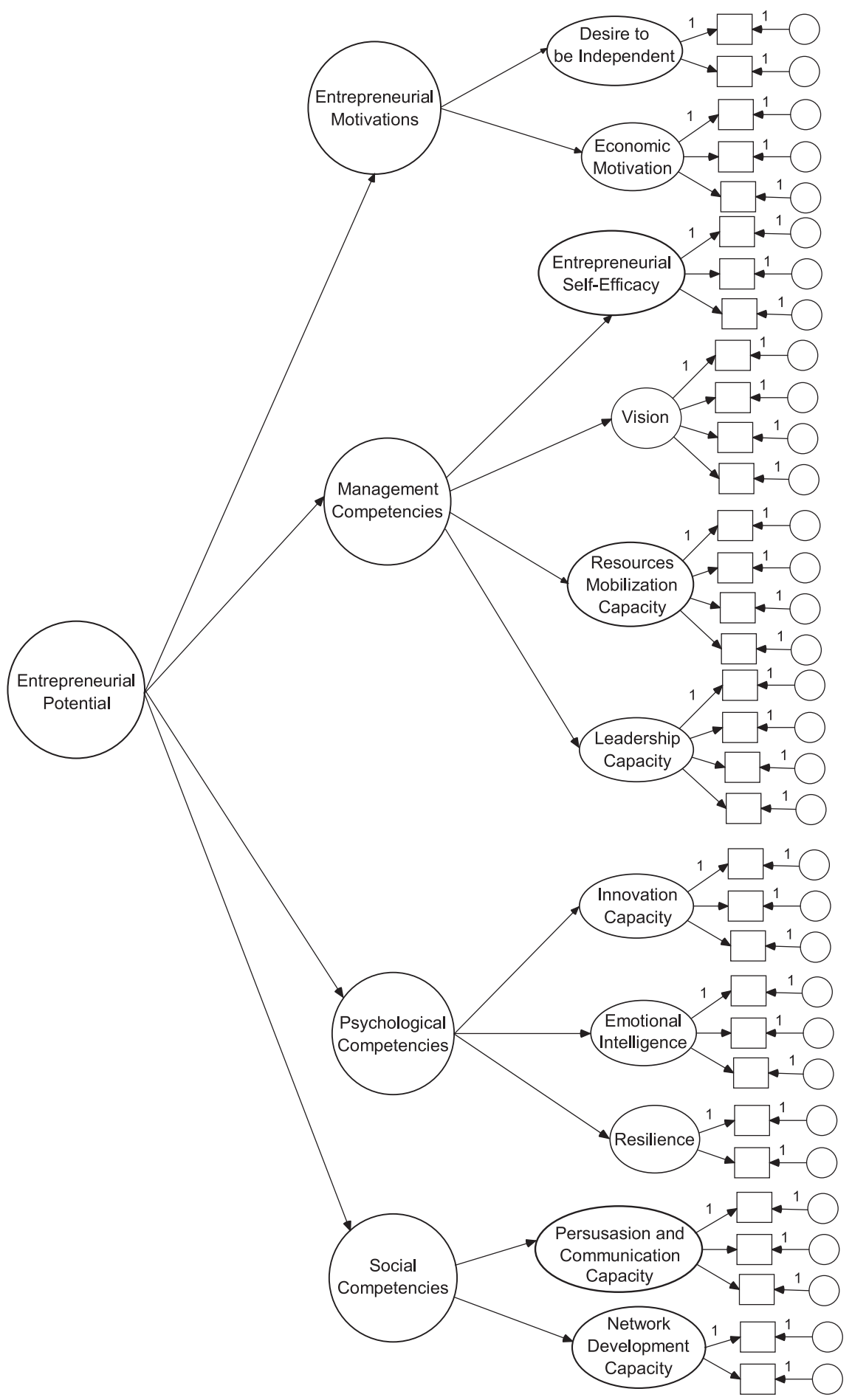

Figure 1. Measurement model of the entrepreneurial potential - confirmatory factor analysis. 


\section{Sample and method}

This study included a sample of 543 young employees whose ages ranged from 18 to 30 years old, with their mean age being $25(S D=2.3)$. They had all been involved in the labor market for a maximum on three years, and $56.6 \%$ were male. The great majority were graduates $(73 \%), 27 \%$ had a master's degree or higher.

\section{Main results}

The confirmatory factor analysis of the EPAI model for the young employee sample $\left(\chi^{2}=1090.38 ;\right.$ d.f. $=454 ; p<0.01 ; \chi^{2} /$ d.f. $=2.40 ; C F I=0.90 ; R M S E A=0.04 ;$ $S R M R=0.04)$ evidences an adequate fit of the data to the model. The standardized regression coefficients of the four main dimensions for the young employee sample are: $B_{\text {entrepreneurial motivation }}=0.44^{* *} ; B_{\text {management }}$ competencies $=0.96^{* *} ; B_{\text {psychological }}$ competencies $=0.90^{* *} ;$ and $B_{\text {social competencies }}=0.67^{* *}{ }^{* *} p<0.05$.

The multi-group confirmatory factor analysis, including both university students and the young employees, evidenced good fit indexes $\left(\chi^{2}=1594.32 ;\right.$ d.f. $=908 ; p<0.01$; $\chi^{2} /$ d.f. $\left.=1.76 ; C F I=0.89 ; R M S E A=0.03\right)$ suggesting that there is structural invariance in the entrepreneurial potential construct. In other words, the structure of the entrepreneurial potential construct is both suitable for university students and young employees.

The 11 subdimensions' mean values and factor intercorrelations among the university students (study 2a) and the young employees (study 2b) are presented in Table 1. For both samples, the network development capacity presents the lowest mean value and the entrepreneurial self-efficacy presents the highest mean value. The reliability, computed for both samples, is shown on the diagonal of Table 1 .

In Table 2 we present the descriptive analysis, correlation matrix, and construct reliability of the four main dimensions of the entrepreneurial potential among the university students and the young employees.

The results on the correlation matrix evidence that there is a significant correlation pattern among the great majority of the subdimensions, as the confirmatory factor analysis suggested. Yet, the resilience is negatively correlated with the other subdimensions on the young employees' sample.

\section{Study 3 - Convergent and discriminant validity}

In selecting a measure as a standard of comparison to assess convergent validity, we sought the entrepreneurial attitude scale that seemed most likely to compete successfully with our measure of entrepreneurial potential. We expect that entrepreneurial potential is related to the enterprise potential in young people measured through attitudes towards characteristics associated with entrepreneurship (Athayde 2009). The attitudes towards enterprise test for young people - ATE test - developed by Athayde (2009) measures four dimensions: leadership; creativity; achievement; and personal control.

In selecting an approach to assess entrepreneurial potential discriminant validity, we chose an entrepreneurial intention measure and locus of control. In fact, entrepreneurial intention as used in the study of Zhao, Seibert, and Hills (2005) allows us to differentiate individuals with different patterns of intentions to become entrepreneurs. The positive relationship between the internal locus of control to an individual's propensity to engage in entrepreneurial activity has been identified in literature in several studies and can also differentiate entrepreneurial behavior (for example, Gartner 1985). 


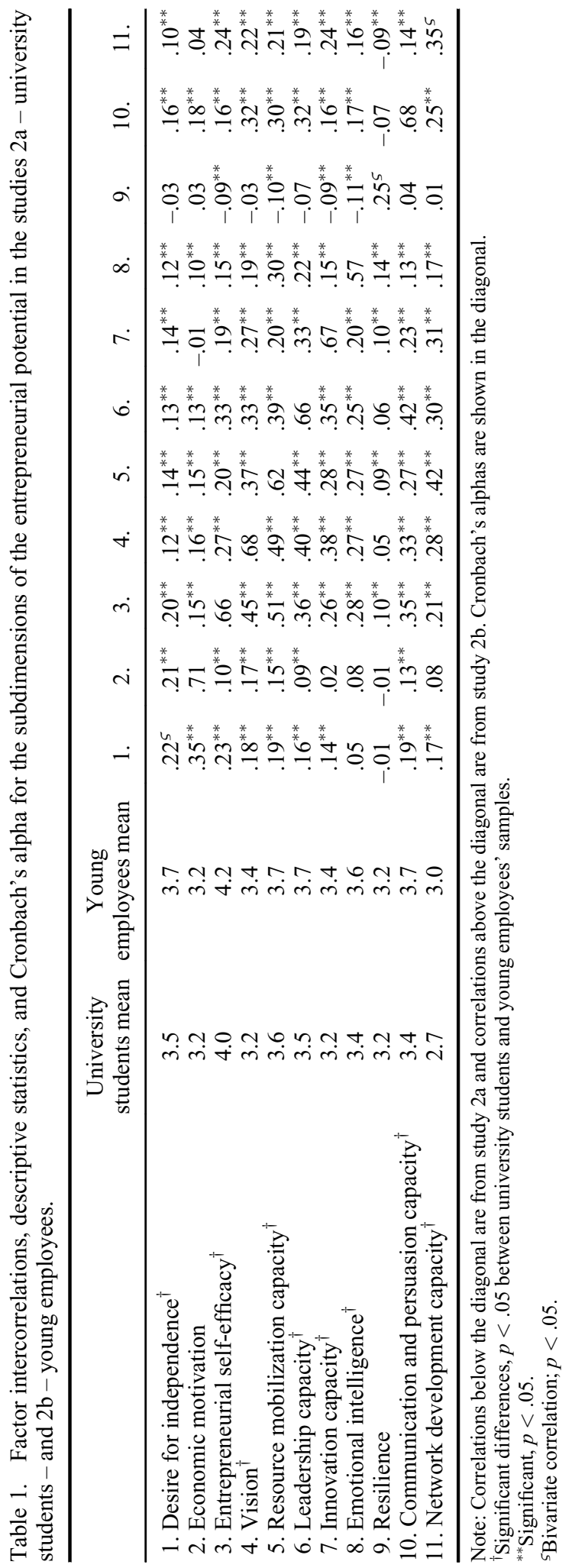


Table 2. Mean values, correlations, and construct reliability of the four main dimensions of the entrepreneurial potential of the university students (study $2 a$ ) and young employees (study $2 b$ ).

\begin{tabular}{lcccccc}
\hline & $\begin{array}{c}\text { University } \\
\text { students mean }\end{array}$ & $\begin{array}{c}\text { Young } \\
\text { employees mean }\end{array}$ & 1. & 2. & 3. & 4. \\
\hline 1.Entrepreneurial motivation $^{\dagger}$ & 3.3 & 3.4 & .67 & $.26^{* *}$ & $.12^{* *}$ & $.20^{* *}$ \\
2.Management competencies $^{\dagger}$ & 3.6 & 3.8 & $.25^{* *}$ & .88 & $.31^{* *}$ & $.47^{* *}$ \\
3.Psychological competencies $^{\dagger}$ & 3.3 & 3.4 & .08 & $.43^{* *}$ & .66 & $.19^{* *}$ \\
4.Social competencies $^{\dagger}$ & 3.1 & 3.4 & $.22^{* *}$ & $.51^{* *}$ & $.28^{* *}$ & .78 \\
\hline
\end{tabular}

Note: Correlations below the diagonal are from study $2 \mathrm{a}$ and correlations above the diagonal are from study $2 \mathrm{~b}$.

Cronbach's alpha is shown in the diagonal.

${ }^{\dagger}$ Significant differences, $p<.05$ between university students and young employees’ samples.

** Significant differences, $p<.05$.

To conduct the convergent and discriminant validity tests we developed an overall measure on entrepreneurial potential based on the weighted results among the four dimensions of the EPAI items. This composite was used to test the relationships among variables.

Based on previous research, and as discriminant validity evidences, we expect that: (1) a high entrepreneurial intention will be more strongly related to the overall measure on the entrepreneurial potential than low entrepreneurial intentions; (2) external locus of control will not be related to the overall measure on the entrepreneurial potential; and (3) internal locus of control will differentiate individuals with high and low levels on the overall measure on the entrepreneurial potential.

\section{Sample and method}

To address these issues, we asked 499 young people who were competing for an internationally funded internship (62\% male) to complete the EPAI inventory, the ATE test, entrepreneurial intentions, and locus of control scales. Their ages ranged from 20 to 30 years, the mean age was $25(S D=2.03)$. The majority were graduates $(55 \%)$ and $45 \%$ had a master's or higher degree. Most of the participants were unemployed (63\%), 23\% were employees, $11 \%$ were university students, and 3\% were freelancers.

For all measures, respondents were asked to indicate the extent to which they agreed or disagreed with each statement, using a 5-point scale, ranging from 1 (disagree completely) to 5 (agree completely).

\section{Main results}

The attitudes towards enterprise for young people - ATE test (Athayde 2009) included 18 items comprising four dimensions. The leadership scale was measured by six items $(\alpha=$ $0.75 ; M=3.69 ; S D=0.52)$. The creativity scale was measured by four items $(\alpha=0.67$; $M=4.36 ; S D=0.47)$. The achievement scale included four items $(\alpha=0.61 ; M=3.25$; $S D=0.40)$. The personal control scale was measured by four items $(\alpha=0.62 ; M=3.78$; $S D=0.52)$. The complete scale evidenced an internal consistency of $0.70(M=3.77$; $S D=0.31)$.

The entrepreneurial intention was measured with four items, following Zhao, Seibert, and Hills' (2005) operationalization. Participants had to rate how interested they were in engaging in typical entrepreneurial activities: starting a business, acquiring a small business, starting and building a high-growth business, and acquiring and building a company into a high-growth business $(\alpha=0.81 ; M=3.85 ; S D=0.84)$. 
Table 3. Discriminant validity in study 4.

Overall entrepreneurial potential measure

High entrepreneurial intention

Low entrepreneurial intention

High internal locus of control

$.28^{* *}$

Low internal locus of control

$.30^{* *}$

High external locus of control

$.20^{* *}$

Low external locus of control

$-.03$

$-.07$

${ }^{* *} p<.05$.

The internal locus of control was measured with four items, following the Levenson (1973) measurement $(\alpha=0.68 ; M=4.06 ; S D=0.44)$. The external locus of control was also measured with four items adapted from the Levenson (1973) scale $(\alpha=0.66 ; M=$ 2.42; $S D=0.66)$.

The entrepreneurial potential was measured in accordance with the EPAI. Reliable psychometric characteristics of the scale were again supported, as in the previous studies.

Results show that the overall measure on the entrepreneurial potential is positively and significantly related with the ATE test $(r=0.36, p<0.05)$, and to the four scales on the ATE test: $r_{\text {leadership scale }}=0.48^{* *} ; r_{\text {creativity scale }}=0.10^{* *} ; r_{\text {achievement scale }}=0.24^{* *} ; r_{\text {per- }}$ sonal control scale $=0.11^{* *}\left({ }^{* *} p<0.05\right)$.

To assess discriminant validity, we centered all the variables and then we created high and low levels in the discriminant variables. We performed regression analysis to assess the relationship pattern between the discriminant variables and the entrepreneurial potential.

Results evidenced that high and low entrepreneurial intentions are positively associated with the overall measure on the entrepreneurial potential $\left(\beta_{\text {high Entrep.Intention }}=0.28\right.$; $\beta_{\text {low Entrep.Intention }}=0.16 ; p<0.05$ ) although, as predicted, the association is stronger with high entrepreneurial intention. The internal locus of control is also positively associated with overall measure on the entrepreneurial potential, at both high and low levels of intention $\left(\beta_{\text {high Internal Locus Control }}=0.30 ; \beta_{\text {low Internal Locus Control }}=0.20 ; p<0.05\right)$, and, once again, the association is stronger with high levels of internal locus of control, as predicted. With regard to the external locus of control, results show that there is no association with overall measure on the entrepreneurial potential $\left(\beta_{\text {high External Locus Control }}=\right.$ $-0.03 ; \beta_{\text {low External Locus Control }}=-0.07 ; p<0.05$ ). Results are described in Table 3 .

The results of study 3 show evidence of convergent and discriminant validity of the entrepreneurial potential. The overall measure on the entrepreneurial potential is associated with the ATE test, and with its subscales, supporting that both scales measure similar constructs (convergent validity). The results from entrepreneurial intention and internal locus of control reveal that the overall measure on the entrepreneurial potential discriminates among participants with high and low levels of both variables. In addition, they show that the external locus of control is not associated with the overall measure on the entrepreneurial potential.

\section{Study 4 - Comparing entrepreneurial potential among university students, young employees, and entrepreneurs}

In the study 4, we compared the entrepreneurial potential results among three different samples: university students, young employees, and entrepreneurs. We predict that the instrument will discriminate between different groups of individuals. 
The entrepreneurs have had experience launching and managing successful ventures, so we can expect that they are higher on the entrepreneurial potential measure. Moreover, we expect that entrepreneurial potential is related to performance and, in fact, entrepreneurs as a group have the highest performance in the entrepreneurship process. Thus, entrepreneurs are conceptualized as a success group in the entrepreneurial potential testing.

The university students are individuals with no entrepreneurial or working experience, and thus we expect that their scores for entrepreneurial potential will be lower. The young employees got their jobs through a competitive selection process and have work experience. We expected that their scores on the entrepreneurial potential measure would be between the university students' and the entrepreneur groups' scores.

\section{Sample and measures}

Study 4 involves three different samples: university students (study 2a); young employees (study $2 \mathrm{~b}$ ) and entrepreneurs. The entrepreneur sample included 92 participants, $72 \%$ were male, with ages ranging from 22 to over 73 years old $(M=42 ; S D=12)$. Most of the entrepreneurs were university graduates or had a higher degree $(51 \%)$ and the others had attended high school or had a college diploma. These entrepreneurs owned start-ups from different sectors, such as tourism and leisure services, medical and health care, software technology, marketing and design, and cafes and restaurants. A small percentage of the entrepreneurs $(5 \%)$ had already launched more than one business.

\section{Main results}

The measurement model of entrepreneurial potential operationalized through the EPAI was tested on the entrepreneur sample. However, and due to the sample size, only the four main dimensions of the confirmatory model construct were tested. The results evidence adequate fit indexes. More specifically, the entrepreneurial motivation $\left(\chi^{2}=5.69\right.$; d.f. $=4 ; p=0.22 ; \chi^{2} /$ d.f. $\left.=1.43 ; C F I=0.98 ; R M S E A=0.06\right)$, the management competency $\left(\chi^{2}=88.55 ;\right.$ d.f. $=83 ; p=0.32 ; \chi^{2} /$ d.f. $\left.=1.07 ; C F I=0.98 ; R M S E A=0.03\right)$, the psychological competency $\left(\chi^{2}=28.51 ; d . f .=23 ; p=0.20 ; \chi^{2} / d . f .=1.24 ; C F I=0.90\right.$; $R M S E A=0.05)$ and the social competency $\left(\chi^{2}=12.22 ; d . f .=8 ; p=0,14 ; \chi^{2} / d . f .=\right.$ $1.53 ; C F I=0.92 ; R M S E A=0.06)$ models fit the entrepreneur sample. This result supports that the entrepreneurial potential model is suitable for entrepreneurs.

We next compared the mean value of the subdimensions of the entrepreneurial potential among the university students, the young employees and the entrepreneurs. There are significant statistical differences between the entrepreneurs and the other groups with regard to the mean values of desire for independence, entrepreneurial self-efficacy, vision, resource mobilization capacity, leadership capacity, innovation capacity, emotional intelligence, communication and persuasion capacity, and network development capacity. Figure 2 shows that the entrepreneurs have a higher mean value than the university students and the young employees.

Similarly, the comparison in the four main dimensions of the entrepreneurial potential makes a further contribution to the validity of the EPAI. There are significant differences between the entrepreneurs and the other groups with regard to entrepreneurial motivations, management competencies, psychological competencies, and social competencies. Figure 3 shows that the entrepreneurs also evidence higher mean values in these dimensions. 


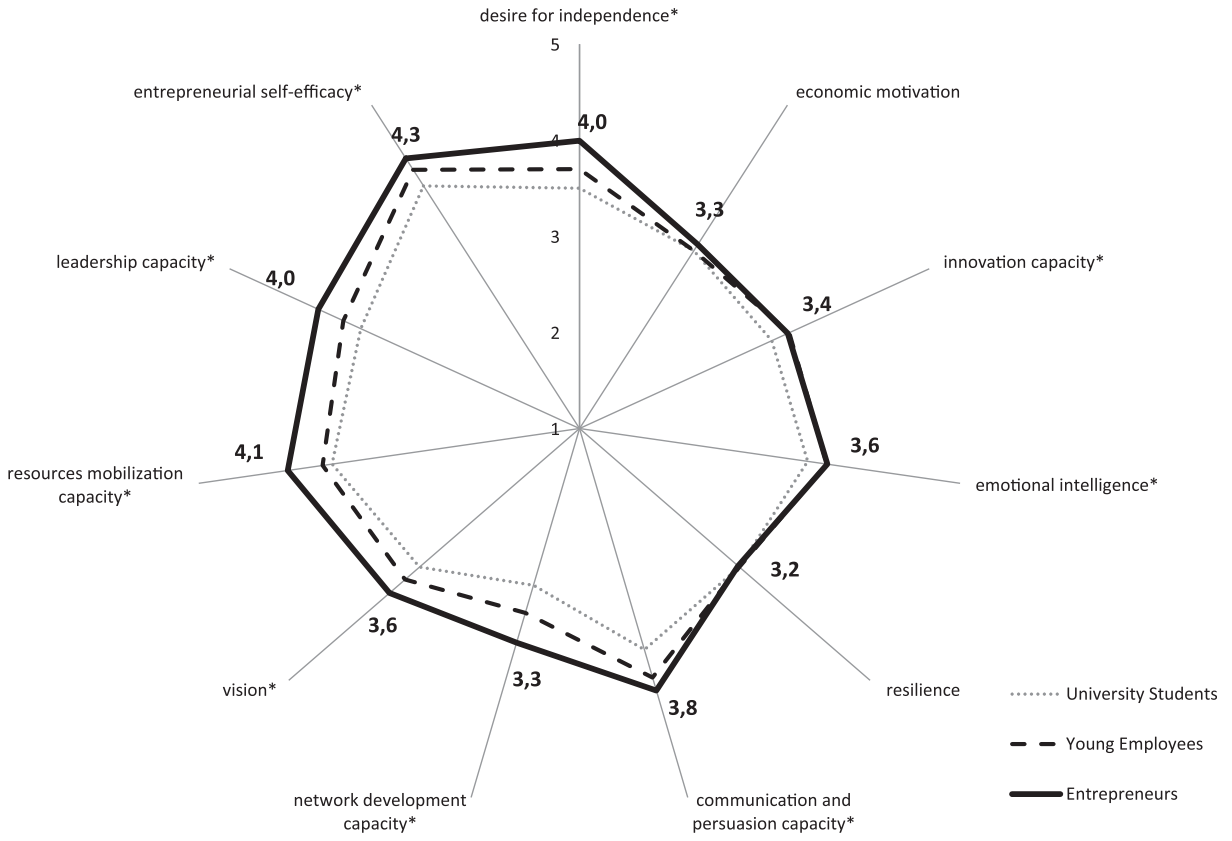

Figure 2. Comparison of the mean values in the 11 subdimensions of the entrepreneurial potential of the university students, young employees, and entrepreneurs.

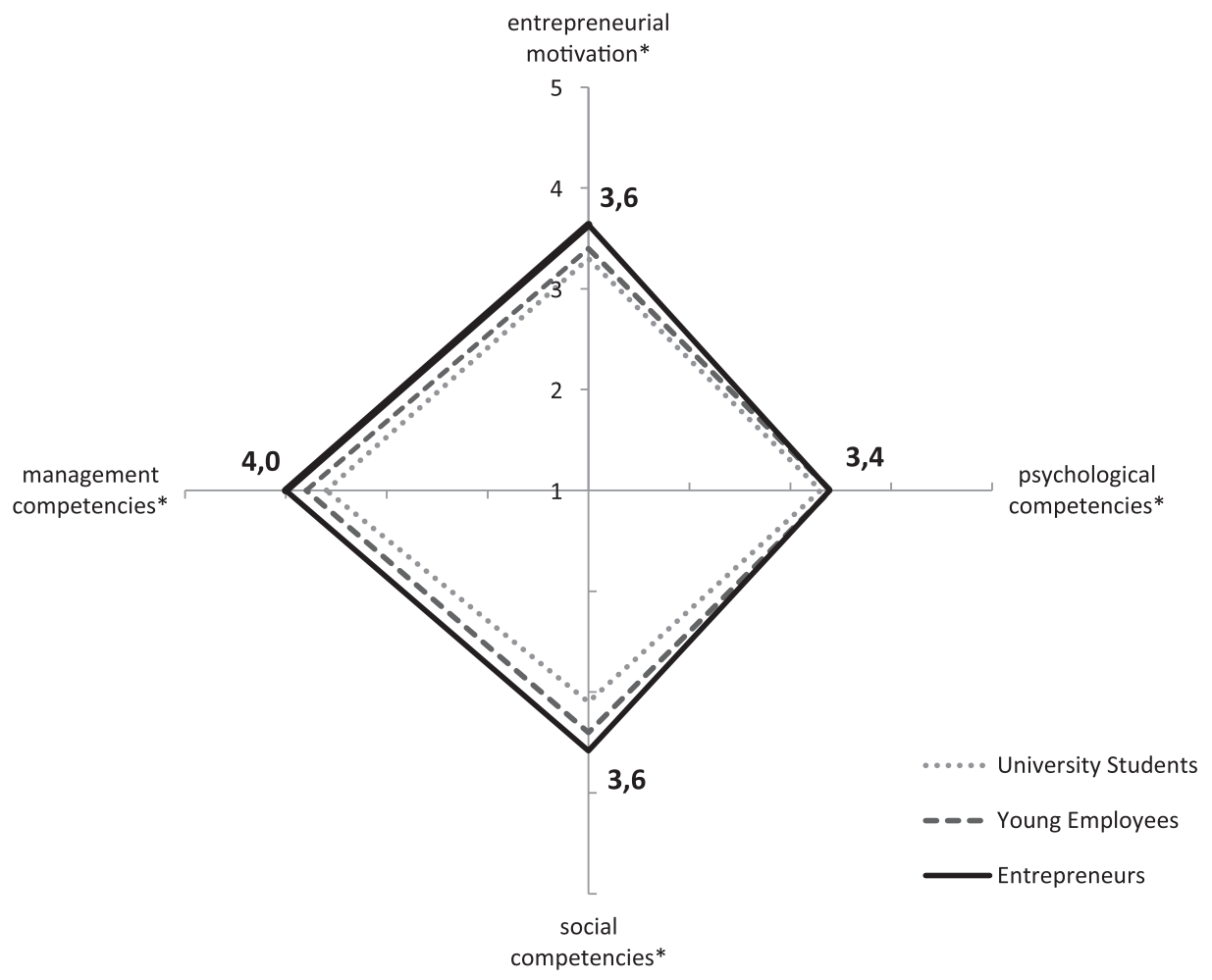

Figure 3. Comparison of the mean values in the four main dimensions of the entrepreneurial potential of the university students, young employees, and entrepreneurs. 


\section{General discussion}

This study presented a theoretical model regarding the entrepreneurial potential construct and four studies on its empirical validation. More specifically, we developed a theoretical model integrating the main differentiating characteristics of entrepreneurs evidenced in the prior literature and in an exploratory empirical study.

The proposed entrepreneurial potential theoretical model comprised four main dimensions - entrepreneurial motivation, management competencies, psychological competencies, and social competencies - and 11 subdimensions - desire for independence, economic motivation, entrepreneurial self-efficacy, vision, mobilization resources capacity, leadership capacity, innovation capacity, emotional intelligence, resilience, communication and persuasion capacity, and network development capacity. Our studies indicated that the proposed new measure for assessing entrepreneurial potential - the EPAI - had good psychometric properties.

Study 3 analyzed the relationship between the entrepreneurial potential measure and the attitude towards enterprise scale, showing the convergent validity of the proposed measure. This study also showed that the entrepreneurial potential scale successfully discriminated among individuals with high and low entrepreneurial intention and internal locus of control. Furthermore, it showed that entrepreneurial potential was not related to the external locus of control.

To assess its strength in distinguishing among different groups with regard to alternative entrepreneurship stages, study 4 compared the scores of the entrepreneurial potential scale among university students, young employees, and entrepreneurs. Results evidenced that the three groups showed significant differences in the four main dimensions, and entrepreneurs scored higher in all four.

This result supports the premise that entrepreneurial potential is related to entrepreneurial activity, suggesting that this tool can predict entrepreneurial intention: the higher an individual scores on entrepreneurial potential, the greater their probability of being an entrepreneur, and to engage in entrepreneurial activities (that is, to have an entrepreneurial intention).

Entrepreneurial intention is related to the will and wish of considering the creation of a new venture (for example, Bird and Jelinek 1988), and is closer to the actual behavior. The individual forms his or her entrepreneurial intention based on a conjunction of perceptions (for example, Liñán and Chen 2009) and a positive or a negative intention might result from them. Entrepreneurial potential, as we conceive it, refers to a latent construct that is the expression of a developmental profile of the most typical competencies and motives among successful entrepreneurs. Nevertheless, entrepreneurial potential and intention are not competitive constructs, and they are both needed in entrepreneurship theory. An individual should need to assess his or her entrepreneurial potential before engaging in an entrepreneurial intention.

The higher results may be due to the nature of the dimensions assessed in the EPAI. More specifically, the EPAI assesses competencies and these are variable dimensions depending on previous experience, knowledge acquisition, and necessity. Our evidences may also be explained by the entrepreneurs' greater previous experience and knowledge, which would have enhanced their competency scores.

\section{Theoretical and methodological contributions}

The present study presents a contribution to the theoretical development of the literature on the characteristics of entrepreneurs, a matured research field in entrepreneurship research (Blackburn and Kovalainen 2009). Research on the entrepreneurial personality (Chell 
2008) has progressively changed its focus from simply describing personality or psychological characteristics to predicting entrepreneurial behavior and assessing potential. Despite the relevance of personality traits (Brandstätter 2011) in explaining how entrepreneurs think, act, and move, they do not exhaust all the determinants of entrepreneurial behavior. This is mainly because of the varied activities and tasks that entrepreneurs face. Thus, our study goes beyond personality traits and is focused on the competencies because they represent the flexible, learnable, and dynamic criteria of entrepreneurship activity.

In this sense, our study also provides a contribution to the operationalization of the entrepreneurial potential construct, with the validation of an inventory. Moreover, previous studies on entrepreneurial potential did not present a theoretical model of convergence, but only a description of the various psychological and social dimensions (Raab, Stedham, and Neuner 2005).

This study enhances the importance of individual characteristics and skills included in the entrepreneurial potential model, reinforcing prior empirical results and strengthening comparisons with theoretical propositions. For example, Baron and Markman (2000) argued that social skills were highly important in the effectiveness of the behavior of the entrepreneur, and the present data supports that proposition.

Moreover, the development of a model of entrepreneurial potential such as the one we propose, creates the possibility to argue that motivational aspects (McClelland 1965), competencies, and attitudes can be integrated and that all contribute to the same scope of entrepreneurial potential.

Our theoretical approach does not argue that these four dimensions capture all important aspects of entrepreneurial potential. The cognitive approach to the study of entrepreneurship points to the possibility that entrepreneurial competency may also be related to intelligence. Cognitive abilities, such as general mental ability, have been identified as the strongest predictors of performance (Ones, Viswesvaran, and Dilchert 2005). Thus, we suggest that it is important to include cognitive ability measures such as those used during job recruitment, when assessing an individual's potential to be an entrepreneur. Moreover, it is suggested that typical entrepreneurial traits like opportunity recognition, proactive personality, self-efficacy, social competence, and intuition are primarily related to the cognitive capability (Chell 2008).

Despite the fact that our model and theoretical argument are based on the individual level, we do not minimize the influence of the environmental factors in the process of emergence of the entrepreneurial potential for potential entrepreneurs (for example, Krueger and Brazeal 1994). The environment is determinant for creating a setting that is more favorable for the development of an increasing entrepreneurial activity. In fact, an entrepreneurship phenomenon is a by-product of multi-level interactions and systems (for example, Shepherd 2011). Thus there are top-down level effects (that is, influence of higher level contextual factors on lower levels of the phenomena) in such a way that the environmental context characteristics influence the individual's entrepreneurial potential. Similarly, we expect that there are bottom-up level effects in such a way that the lower level properties aggregate to form collective phenomena (that is, the individual's entrepreneurial potential can be translated in higher level of analysis variables such as organizational entrepreneurial potential or country-level entrepreneurial potential).

\section{Limitations and practical implications}

Despite the contributions this research makes, there are nevertheless some limitations. First, we have some concerns about our samples as the employee sample (study 2b), only 
include young people, leaving the patterns of entrepreneurial potential for workers with greater experience still to be explored. It is also crucial to analyze the results of a greater sample of entrepreneurs, which could then be used as a baseline benchmark for other groups. Moreover, the characteristics of the samples used in our studies may have promoted a maturation effect on the results among entrepreneurs, young employees, and university students.

Second, the studies we have presented are not sufficient to develop a complete validation process of the entrepreneurial potential scale. Validation is a long process and further tests should be developed focusing on incremental and differential validity, which is particularly critical in the assessment procedures (Kline 1993; Spector 1992). Moreover, it is critical to develop predictive validity tests where the EPAI should assess exactly the same individuals in a longitudinal design, following individuals from the would-be entrepreneurs stage to the effective start-up launch.

To address the limitations referred to above, and to continue developing the validity of the entrepreneurial potential scale, there is a long succession of studies to be conducted. Future research should focus on predictive validity, following entrepreneurs, would-be entrepreneurs, and entrepreneurship students over time. Another route research could take concerns cross-cultural research on the entrepreneurial potential scale and try to compare scores in different countries.

As far as practical implications are concerned, the EPAI can become a tool of high value to the community, since it allows every individual who is thinking about beginning an entrepreneurial career to assess the level of entrepreneurial potential as well as those dimensions that need to be developed. EPAI can be a self-assessment tool to be used by future entrepreneurs and students to assess their psychosocial profile in these four main dimensions that are critically related to entrepreneurship activity, and thus enhance entrepreneurial excellence (Baron 2013). After completing the survey and results are generated, the individuals can have access to their entrepreneurial potential profile and identify in which areas they need more training. Individuals who exhibit a high profile among the competencies and motives included on the entrepreneurial potential model, have a greater chance to become successful entrepreneurs. Individuals who express some weakness in certain competencies or motives can have the chance to engage in training programs in order to develop them. By doing this self-assessment, it is possible to increase entrepreneurial intentions and to ensure a greater chance for success and survival rates.

As argued before, entrepreneurial potential is prior to entrepreneurial intentions, and if we look to the pre-emergence stages of the entrepreneurship process, it is important to clarify the role, distinctiveness, and usefulness for practitioners of both constructs. For those individuals who have some weaknesses in the entrepreneurial potential dimensions, it is critical that they train and develop those competencies or motives before they construct a positive entrepreneurial intention. Thus, the EPAI is also a good tool for practitioners to guide future entrepreneurs to the adequate training programs before they are actively engaged in entrepreneurial tasks.

Over the last decade, much attention has been paid to competency-based education, and its relevance to entrepreneurship education and training at the university level as well as other training venues has become apparent. A basic premise of this movement is that an educational position based on competency development can facilitate learning in a society characterized by complexity and rapid changes. Thus, our focus on the assessment of a preparedness to engage in typical entrepreneurship activities may also be relevant for entrepreneurship education debates. In an educational setting the interest is in 
individual-level competency as we attempt to help students become more skilled and motivated to start and succeed in new ventures (Bird 1995). Furthermore, the nature of competencies and motivational aspects included in the entrepreneurial potential construct is committed to the possibility to train, change, and develop the competencies and motives that are associated with the entrepreneurial potential. More specifically, desire for independence and economic motivation are two entrepreneurial motives that can be stimulated at training settings, as well as asking for the individuals to reflect on other motivations associated to entrepreneurship (for example, Santos, Curral, and Caetano 2010). As motivation is one of the best predictors of entrepreneurial activity, it is crucial to include in training programs and courses actions that make individuals be aware of their motivations and how determinant they will be.

Since entrepreneurial potential is mostly composed of competencies, it follows that specific training can be designed to develop these competencies. In this sense, the EPAI helps to identify skills and competencies requiring development and training in a group of students. Thus, the EPAI can become important in designing or adjusting the curriculum, for diagnosing the dimensions in which students have the greatest difficulty, and in signaling the need for skills development. Thus, making it possible to compare different potential entrepreneurs, and help in investment decision-making (Santos and Caetano 2010) and/or the formation of entrepreneurial teams.

Against a background of economic and social crisis, entrepreneurship presents itself increasingly as a solution for self-employment (de Nardi and Villamil 2009). In this sense, the EPAI can play a critical role in the early stages of the entrepreneurial process: assessing the main skills necessary to develop entrepreneurial business success.

\section{Acknowledgements}

We would like to thank our colleagues Sílvia Fernandes Costa (ISCTE-IUL) and Paola Spagnoli (Seconda Università di Napoli) who cooperated on data collection and commented on previous drafts of the present paper, as well as Sílvia Silva and Ana Passos (ISCTE-IUL) for their comments and suggestions.

\section{Funding}

Part of this work was supported by the Foundation for Science and Technology, Portugal [grant number SFRH/BD/45768/2008] and [grant number PEst-OE/EGE/UI0315/2011].

\section{Notes on contributors}

Susana Correia Santos has a $\mathrm{PhD}$ in human resources management at Instituto Universitário de Lisboa (ISCTE-IUL). The main research areas include the psychosocial processes of entrepreneurship, business opportunity recognition, and cross-cultural entrepreneurship processes.

António Caetano has a $\mathrm{PhD}$ in organizational and social psychology and is a full professor at Instituto Universitário de Lisboa (ISCTE-IUL), where he teaches courses on organizational behavior and human resources. The main research areas include entrepreneurship, performance appraisal, training evaluation, organizational social exchange processes, and subjective well-being at work.

Luís Curral has a $\mathrm{PhD}$ in organizational and social psychology and is assistant professor at Faculty of Psychology, Lisbon University, where he teaches courses on organizational theory and cognition, and organizational behavior. The main research areas include the entrepreneurship, team work, and innovation processes. 


\section{References}

Ajzen, I. 1991. "The Theory of Planned Behavior." Organizational Behavior and Human Decision Processes 50 (2): 179-211.

Ajzen, I. 2002. "Perceived Behavioral Control, Self-efficacy, Locus of Control, and the Theory of Planned Behavior." Journal of Applied Social Psychology 32 (4): 665-683. doi: 10.1111/ j.1559-1816.2002.tb00236.x.

Anderson, A., and L. Warren. 2011. "The Entrepreneur as Hero and Jester: Enacting the Entrepreneurial Discourse." International Small Business Journal 29 (6): 589-609. doi:10.1177/ 0266242611416417.

Athayde, R. 2009. "Measuring Enterprise Potential in Young People." Entrepreneurship: Theory and Practice 33 (2): 481-500.

Bandura, A. 1997. Self-efficacy: The Exercise of Control. New York: Freeman and Co.

Baron, R. A. 2013. Enhancing Entrepreneurial Excellence: Tools for Making the Possible Real. Cheltenham: Edward Elgar.

Baron, R., and G. D. Markman. 2000. "Beyond Social Capital: The Role of Social Skills in Entrepreneurs' Success." Academy of Management Executive 14 (1): 106-116.

Baron, R., and S. Shane. 2008. Entrepreneurship: A Process Perspective. Mason, OH: ThomsonSouthwestern Publishing Co.

Baron, R., and J. Tang. 2009. "Entrepreneurs' Social Skills and New Venture Performance: Mediating Mechanisms and Cultural Generality." Journal of Management 35 (2): 282-306.

Baughn, C. C., J. S. R. Cao, L. T. M. Le, V. A. Lim, and K. E. Neupert. 2006. "Normative, Social and Cognitive Predictors of Entrepreneurial Interest in China, Vietnam and the Philippines." Journal of Developmental Entrepreneurship 11 (1): 57-77.

Baum, J. R., M. Frese, R. Baron, and J. A. Katz. 2007. "Entrepreneurship as an Area of Psychology Study: An Introduction." In Psychology of Entrepreneurship, edited by R. Baum, M. Frese, and R. Baron, 1-18. Mahwah, NJ: Lawrence Erlbaum.

Baum, J. R., and E. A. Locke. 2004. "The Relationship of Entrepreneurial Traits, Skills, and Motivation to Subsequent Venture Growth." Journal of Applied Psychology 89 (4): 587-598.

Baum, J. R., E. A. Locke, and S. Kirkpatrick. 1998. "A Longitudinal Study of the Relation of Vision and Vision Communication to Venture Growth in Entrepreneurial Firms." Journal of Applied Psychology 83 (1): 43-54.

Baum, J. R., E. A. Locke, and K. G. Smith. 2001. "A Multidimensional Model of Venture Growth." Academy of Management Journal 44 (2): 292-303.

Bird, B. 1995. "Toward a Theory of Entrepreneurial Competency." In Advances in Entrepreneurship, Firm Emergence and Growth, edited by J. A. Katz and R. H. Brockhaus, 51-72. Greenwich, CT: Jai Press Inc.

Bird, B., and M. Jelinek. 1988. "The Operation of Entrepreneurial Intentions." Entrepreneurship, Theory and Practice 13 (2): 21-29.

Birley, S. 1985. "The Role of Networks in the Entrepreneurial Process." Journal of Business Venturing 1 (1): 107-117.

Blackburn, R., and A. Kovalainen. 2009. "Researching Small Firms and Entrepreneurship: Past, Present and Future." International Journal of Management Reviews 11 (2): 127-148.

Brandstätter, H. 2011. "Personality Aspects of Entrepreneurship: A Look at Five Meta-analyses." Personality and Individual Differences 51 (3): 222-230.

Brice, Jr., J., and M. Nelson. 2008. "The Impact of Occupational Preferences on the Intent to Pursue an Entrepreneurial Career." Academy of Entrepreneurship Journal 14 (1): 13-36.

Byrne, B. M. 2004. Testing for Multi-Group Invariance Using AMOS Graphics: A Road Less Travelled. Structural Equation Modeling 11 (2): 272-300.

Carey, T. A., D. J. Flanagan, and T. B. Palmer. 2010. "An Examination of University Student Entrepreneurial Intentions by Type of Venture." Journal of Developmental Entrepreneurship 15 (4): 503-517.

Chell, E. 2008. The Entrepreneurial Personality: A Social Construction. London: The Psychology Press/Routledge.

Chell, E., J. Haworth, and S. Brearley. 1991. The Entrepreneurial Personality: Concepts, Cases, and Categories. London: Routledge.

Chen, C. C., P. G. Greene, and A. Crick. 1998. "Does Entrepreneurial Self-efficacy Distinguish Entrepreneurs from Managers?” Journal of Business Venturing 13 (4): 295-316. 
Crant, M. J. 1996. "The Proactive Personality Scale as a Predictor of Entrepreneurial Intentions." Journal of Small Business Management 34 (3): 42-50.

de Nardi, M., and A. Villamill. 2009. "Entrepreneurship, Finance and Employment." Annals of Finance 5 (3/4): 289-293.

Friborg, O., O. Hjemdal, J. H. Rosenvinge, M. Martinussen, P. M. Aslaksen, and M. A. Flaten. 2006. "Resilience as a Moderator of Pain and Stress." Journal of Psychosomatic Research 61 (2): 213-219.

Gartner, W. B. 1985. "A Conceptual Framework for Describing the Phenomenon of New Venture Creation." Academy of Management Review 10 (4): 696-706.

Greenberger, D. B., and D. L. Sexton. 1988. "An Interactive Model of New Venture Formation." Journal of Small Business Management 26 (3): 1-7.

Harada, N. 2005. "Potential Entrepreneurship in Japan." Small Business Economics 25 (3): 293-304.

Hayward, M. L. A., W. R. Forster, S. D. Sarasvathy, and B. L. Fredrickson. 2010. "Beyond Hubris: How Highly Confident Entrepreneurs Rebound to Venture Again." Journal of Business Venturing 25 (6): 569-578.

Hisrich, R. D. 1985. "The Woman Entrepreneur in the United States and Puerto Rico: A Comparative Study." Leadership and Organizational Development Journal 5 (5): 3-8.

Hmieleski, K. M., and R. A. Baron. 2008. "When Does Entrepreneurial Self-efficacy Enhance Versus Reduce Firm Performance?” Strategic Entrepreneurship Journal 2 (1): 57-72.

Hoehn-Weiss, M. N., C. G. Brush, and R. Baron. 2004. "Putting Your Best Foot Forward? Assessments of Entrepreneurial Social Competence from Two Perspectives." The Journal of Private Equity 7 (4): 17-26.

Hornaday, J., and J. Aboud. 1971. "Characteristics of Successful Entrepreneurs." Personal Psychology 24 (2): 141-153.

Ireland, R. D., M. A. Hitt, and D. G. Sirmon. 2003. "A Model of Strategic Entrepreneurship: The Construct and its Dimensions." Journal of Management 29 (6): 963-989.

Kirkpatrick, S. A., J. C. Wofford, and J. R. Baum. 2002. "Measuring Motive Imagery Contained in the Vision Statement." Leadership Quarterly 13 (2): 139-150.

Klein, K. J., and J. S. Sorra. 1996. "The Challenge of Innovation Implementation." Academy of Management Review 21 (4): 1055-1080.

Kline, P. 1993. Handbook of Psychological Testing. London: Routledge.

Kreiser, P. M., and J. D. Davis. 2010. "Entrepreneurial Orientation and Firm Performance: The Unique Impact of Innovativeness, Proactiveness, and Risk-Taking." Journal of Small Business and Entrepreneurship 23 (1): 39-51.

Krueger, N. F., and D. Brazeal. 1994. "Entrepreneurial Potential and Potential Entrepreneurs." Entrepreneurship: Theory and Practice 18 (3): 91-104.

Krueger, N. F., M. D. Reilly, and A. L. Carsrud. 2000. "Competing Models of Entrepreneurial Intentions." Journal of Business Venturing 15 (5/6): 411-432.

Lee, D. Y., and E. W. K. Tsang. 2001. "The Effects of Entrepreneurial Personality, Background and Network Activities on Venture Growth." Journal of Management Studies 38 (4): 583-602.

Levenson, H. 1973. "Multidimensional Locus of Control in Psychiatric Patients." Journal of Consulting and Clinical Psychology 41 (3): 397-404.

Liñán, F., and Y. W. Chen. 2009. "Development and Cross-cultural Application of a Specific Instrument to Measure Entrepreneurial Intentions." Entrepreneurship Theory and Practice 33 (3): 593-617.

Lord, R. G., C. L. de Vader, and G. M. Alliger. 1986. "A Meta-analysis of the Relation Between Personality Traits and Leadership Perceptions: An Application of Validity Generalization Procedures." Journal of Applied Psychology 71 (3): 402-410.

Lumpkin, G. T., C. C. Cogliser, and D. R. Schneider. 2009. "Understanding and Measuring Autonomy: An Entrepreneurial Orientation Perspective." Entrepreneurship Theory and Practice 33 (1): 47-69.

Marvel, M. R., and G. T. Lumpkin. 2007. "Entrepreneurs Human Capital and Its Effects on Innovation Radicalness." Entrepreneurship: Theory and Practice 31 (6): 807-828.

Mayer, J. D., P. Salovey, and D. R. Caruso. 2000. "Models of Emotional Intelligence.” In Handbook of Intelligence, edited by R. J. Sternberg, 396-420. Cambridge: Cambridge University Press.

McClelland, D. C. 1965. "Need Achievement and Entrepreneurship: A Longitudinal Study." Journal of Personality and Social Psychology 1 (4): 389-392. 
McGee, J. E., M. Peterson, S. Mueller, and J. Sequeria. 2009. "Entrepreneurial Self-efficacy: Refining the Measure." Entrepreneurship: Theory and Practice 33 (4): 965-988.

McMullen, J. S., and D. Shepherd. 2006. "Entrepreneurial Action and the Role of Uncertainty in the Theory of the Entrepreneur." Academy of Management Review 31 (1): 132-152.

Mueller, S. L. 2004. "Gender Gaps in Potential for Entrepreneurship Across Countries and Cultures." Journal of Developmental Entrepreneurship 9 (3): 199-220.

Mueller, S. L., and S. Goić. 2002. "Entrepreneurial Potential in Transition Economies: A View from Tomorrow's Leaders.” Journal of Developmental Entrepreneurship 7 (4): 399-414.

Mueller, S. L., and A. S. Thomas. 2000. "Culture and Entrepreneurial Potential: A Nine Country Study of Locus of Control and Innovativeness." Journal of Business Venturing 16 (1): 51-75.

Nguyen, T. V., S. Bryant, J. Rose, C. Tseng, and S. Kapasuwan. 2009. "Cultural Values, Market Institutions, and Entrepreneurship Potential: A Comparative Study of the United States, Taiwan, and Vietnam." Journal of Developmental Entrepreneurship 14 (1): 21-37.

Ones, D. S., C. Viswesvaran, and S. Dilchert. 2005. "Cognitive Ability in Personnel Selection Decisions." In Handbook of Selection, edited by A. Evers, O. Voskuijl, and N. Anderson, 143-173. Oxford: Blackwell.

Osborne, R. L. 1995. "The essence of entrepreneurial success." Management Decision 33 (7): 4-9.

Raab, G., Y. Stedham, and M. Neuner. 2005. "Entrepreneurial Potential: An Exploratory Study of Business Students in the U.S. and German." Journal of Business and Management 11 (2): $71-88$.

Robinson, P. B., D. V. Stimpson, J. C. Huefner, and K. Hunt. 1991. "An Attitude Approach to the Prediction of Entrepreneurship." Entrepreneurship Theory and Practice 15 (4): 13-31.

Santos, S. C., and A. Caetano. 2010. "Entrepreneurs' Selection Methodology in Social Entrepreneurship Programmes." In Exploring the Dynamics of Entrepreneurship, edited by A. Surdej and K. Wach, 89-017. Toruń: Adam Marszałek Publishing House.

Santos, S. C., L. Curral, and A. Caetano. 2010. "Cognitive Maps in Early Entrepreneurship Stages: From Motivation to Implementation." International Journal of Entrepreneurship and Innovation 11 (1): 29-44.

Schumpeter, J. A. 1934. The Theory of Economic Development. Cambridge, MA: Harvard University Press.

Schwenk, C. R., and C. B. Shrader. 1993. "Effects of Formal Strategic Planning on Financial Performance in Small Firms: A Meta-analysis." Entrepreneurship Theory and Practice 17 (3): 48-53.

Shane, S., E. Locke, and C. J. Collins. 2003. "Entrepreneurial Motivation." Human Resources Management Review 13 (2): 257-279.

Shepherd, D. A. 2011. "Multilevel Entrepreneurship Research: Opportunities for Studying Entrepreneurial Decision Making." Journal of Management 37 (2): 412-420.

Spector, P. E. 1992. Summated Rating Scale Construction. Newbury: Sage.

Spencer, Jr., L. M. and S. Spencer. 1993. Competence at Work: Models for Superior Performance. New York: John Wiley and Sons.

Tan, J., and M. W. Peng. 2003. "Organizational Slack and Firm Performance During Economic Transitions: Two Studies from an Emerging Economy." Strategic Management Journal 23 (13): 1249-1263.

Todorovic, W., and F. K. Schlosser. 2007. "An Entrepreneur and a Leader: A Framework Conceptualizing the Influence of Leadership Style on a Firm's Entrepreneurial Orientation-Performance Relationship." Journal of Small Business and Entrepreneurship 20 (3): 289-307.

Venkataraman, S., S. D. Sarasvathy, N. Dew, and W. R. Forster. 2012. "Reflections on the 2010 AMR Decade Award: Whiter the Promise? Moving Forward with Entrepreneurship as a Science of the Artificial." Academy of Management Review 37 (1): 21-33.

Wong, W., H. Cheung, and P. K. Venuvinod. 2005. "Individual Entrepreneurial Characteristics and Entrepreneurial Success Potential." International Journal of Innovation and Technology Management 2 (3): 277-292.

Zampetakis, L. A., K. Kafetsios, N. Bouranta, T. Dewett, and V. S. Moustakis. 2009. "On the Relationship Between Emotional Intelligence and Entrepreneurial Attitudes and Intentions." International Journal of Entrepreneurial Behaviour and Research 15 (6): 595-618.

Zhao, H., S. Seibert, and G. E. Hills. 2005. "The Mediating Role of Self-efficacy in the Development of Entrepreneurial Intentions.” Journal of Applied Psychology 90 (2): 1265-1272. 